\title{
VZTAHY MEZI ČLENY ZNOVUSLOŽENÝCH RODIN
}

\author{
MARKÉTA NĚMCOVÁ
}

\begin{abstract}
Abstrakt: Čím dál častějším typem rodinného soužití jsou dnes tzv. znovusložené rodiny. V zahraniční literatuře je možné nalézt nemalé množství výzkumů zabývajících se těmito rodinami. $\mathrm{V}$ českém prostředí je ovšem problematika těchto rodin výzkumně opomíjena a je u nás tak velmi málo známo o specifikách a dynamice vztahů mezi jednotlivými členy znovusložených rodin. Vztahy uvnitř těchto rodin jsou poměrně složitě propletené, a to zejména z pohledu dítěte, které získává nevlastního rodiče, nové sourozence či další př́buzné. Zkoumání těchto vztahů tak není jednoduchou záležitostí. Přesto by tyto rodiny neměly být opomíjeny, nebot' rozpad rodiny původní biologické je zátěžovou situací pro všechny její členy a ovlivňuje formování rodiny nové a nemalou měrou i vývoj dětí $\mathrm{v}$ těchto rodinách. Následující text předkládá přehled zjištění převážně zahraničních výzkumných studií zabývajících se znovusloženými rodinami a vztahy mezi jednotlivými členy těchto rodin.
\end{abstract}

Klíčová slova: znovusložené rodiny, nevlastní rodiče, sourozenci, rodinné poradenství

\section{Relationships between members of stepfamilies}

Abstract: Today, so-called reunited families are an increasingly common type of family cohabitation. A considerable amount of research dealing with these families can be found in foreign literature. In the Czech environment, however, the issue of these families is neglected in research and very little is known about the specifics and dynamics of relationships between individual members of reunited families. Relationships within these families are quite intricately intertwined, especially from the point of view of a child who acquires a stepparent, a new sibling or other relatives. Exploring these relationships is not an easy task. Nevertheless, these families should not be neglected, as the disintegration of the original biological family is a stressful situation for all its members and affects the formation of a new family and, to a large extent, the development of children in these families. The following text presents an overview of the findings of mostly foreign research studies dealing with reconstituted families and the relationships between individual members of these families.

Key words: reconstituted families, stepparents, siblings, family counseling https://doi.org/10.14712/23366486.2021.6

\section{Úvod}

Znovusložené rodiny jsou v současnosti typem rodinného uspořádání, se kterým se nejen v praxi, ale také v běžném a osobním životě setkáváme poměrně často. Jedná se o ty rodiny, které vznikají po zániku rodiny původní, biologické, přičemž jeden či oba dospělí v této rodině mají jedno nebo více dětí z předchozího vztahu (Ganong \& Coleman, 
2004; Němcová, 2018). K zániku rodiny původní může dojít bud' na základě rozvodu či rozchodu rodičů, nebo v důsledku úmrtí jednoho z rodičů (Matějček, 1992; Němcová, 2018). Pro označení těchto rodin se mimo pojmu rodina znovusložená uživá též označení rodina nevlastní, smíšená, doplněná, patchworková či rekonstruovaná. Domnívám se, že nejpřesněji vystihuje podstatu tohoto typu rodinného soužití označení rodina znovusložená (Němcová, 2018; Němcová, 2020). Tento pojem nejlépe vystihuje fakt, že v těchto rodinách dochází $\mathrm{k}$ vytvoření rodiny nové po rozpadu rodiny nebo rodin předcházejících.

Obecně lze říct, že existují dva typy znovusložených rodin. Záleží zde na tom, zda děti z předchozího vztahu, které ve znovusložené rodině žijí, má pouze jeden či oba dospělí (rodiče) $\mathrm{v}$ rodině. $\mathrm{V}$ prrípadě, že pouze jeden $\mathrm{z}$ rodičů s sebou prrivádí děti z předchozího vztahu do nové rodiny, mluvíme o tzv. jednoduchých znovusložených rodinách (simple stepfamily). V př́ípadě, že oba dospělí mají děti z prédchozího vztahu, které žijí v nově utvořené znovusložené rodině, jedná se o tzv. komplexní znovusloženou rodinu (complex stepfamily) (Ganong \& Coleman, 2004; Němcová, 2018). V zahraniční literatuře se někdy rovněž hovoří o rodinách nevlastních otců (stepfather families) nebo rodinách nevlastních matek (stepmother families) v závislosti na tom, který z rodičů je nevlastní.

Vztahy uvnitř těchto rodin jsou přitom velmi složité, jejich zkoumání tak rozhodně není jednoduché a složitost těchto vztahů může být naopak pro výzkumníky odrazující. Spletité mohou být vztahy $\mathrm{v}$ těchto rodinách zejména $\mathrm{z}$ pohledu dítěte, které má ve znovusložené rodině pouze jednoho z biologických rodičů (tzv. residenční rodič), př́padně sourozence a zároveň získává nového nevlastního rodiče, nové sourozence a další př́ibuzné. Mimo znovusloženou rodinu ovšem děti často mají druhého biologického (tzv. neresidenčního) rodiče. Situace se samozřejmě stává složitější, pokud oba biologičtí rodiče utvoří nové znovusložené rodiny (Ganong \& Coleman, 2004; Němcová, 2018).

Určitě bychom téma těchto rodin neměli opomíjet, nebot' rozpad původní biologické rodiny je pro všechny její členy zátěžovou situací, která může zásadním způsobem ovlivňovat vztahy mezi členy těchto rodin, formování nové, znovusložené rodiny a nemalou měrou také vývoj dětí $v$ těchto rodinách. Dříve jsme se setkávali s poměrně velkou stigmatizací znovusložených rodin. Ačkoli dnes tomu již tak není a pohled na rodiny znovusložené není vyloženě stigmatizující, může ve společnosti přesto přetrvávat spiše negativní pohled na tyto rodiny. $\mathrm{K}$ tomu může přispívat i negativní obraz těchto rodin v literatuře a filmech, který zde stále přetrvává (Claxton-Oldfield, 2000; Leon \& Angst, 2005; Pasley \& Ihinger-Tallman, 1985). Negativní pohled na tyto rodiny může být důsledkem i tzv. ideologie vlastní rodiny. Tento pojem v zahraniční literatuře označuje jev, kdy biologické, vlastní rodiny jsou společensky přijatelné a žádoucí. Ostatní typy rodinného soužití, včetně rodin znovusložených, jsou poté vnímány jako nežádoucí a deviantní (Ganong \& Coleman, 2004; Němcová, 2018). Tento postoj je ale třeba vyvrátit. Mnohé zahraniční výzkumy poukazují na to, že rodina znovusložená může být vhodnějším prostředím pro dítě než vlastní biologická rodina. Tento fakt rovněž potvrzovali i mnozí respondenti $\mathrm{v}$ rámci výzkumného šetření $\mathrm{k}$ mé diplomové práci na toto téma, nebot' mnozí z nich hodnotili znovusloženou rodinu jako rodinu, která je zcela normální, kde se cítí dobře nebo dokonce lépe než v rodině biologické (Němcová, 2020).

Problematice těchto rodin se $\mathrm{v}$ zahraničí věnuje nemalá pozornost $\mathrm{v}$ oblasti výzkumu. U nás jsou znovusložené rodiny v rámci psychologického výzkumu opomíjeny. To může být ovlivněno, jak již bylo řečeno, složitostí vztahů uvnitř těchto rodin, což činí výzkum 
náročnější a komplikovanější. Výzkumně podložená fakta přitom mohou být východiskem pro následné praktické intervence při práci s těmito rodinami. Ve svých textech se u nás těmto rodinám hojně věnoval prof. Matějček (např. 1992), jehož zkušenosti z praxe jsou velmi cenné.

V následujícím textu, který je samostatnou kapitolou v rámci mé diplomové práce (Němcová, 2020) na téma , Vztahy mezi členy znovusložených rodin a osobní pohoda ditěte “, je předložen přehled zjištění a výsledků zahraničních studií. Většina výzkumů se zabývala problematikou těchto rodin z hlediska modelu, kdy děti po rozpadu původní rodiny žijí s matkou, která si najde nového partnera. Jedná se tedy o tzv. rodiny nevlastních otců (stepfather families). Tento model znovusložených rodin je asi modelem nejčastějším, proto se tento model odráží a je nejčastěji popisován i v tomto textu (Němcová, 2018; Němcová, 2020).

\section{Vztahy a jejich vývoj uvnitř znovusložených rodin}

V rámci každé znovusložené rodiny probíhá vývoj zcela individuálně, nelze hovořit o jednom schématu vývoje těchto rodin. Pro vývoj znovusložené rodiny a proces „stávání se rodinou“ jsou klíčové tři základní oblasti - udržování hranic, solidarita a adaptace. $\mathrm{S}$ těmito oblastmi přišli autoři kvalitativní studie, která analyzovala přepisy rozhovorů $\mathrm{s}$ rodiči a dětmi ze znovusložených rodin. Na základě toho autoři také popisují pět možných scénářů vývoje znovusložené rodiny v prvních čtyřech letech. První možný scénář nazvali zrychlený (accelerated). Rodiny, které spadaly do tohoto scénáře, zažívaly velmi rychle pocit, že jsou rodina. Jednotliví členové měli od samého počátku očekávání, že budou typickou, tradiční rodinou, což se projevovalo rychlým rozdělením rolí a ustálením rodinných norem a zvyků, tradic. I zde se ovšem objevovaly konflikty. Přechod a vytvoření nové rodiny byl ovšem relativně bezproblémový, a to zejména díky vysoké schopnosti adaptace a vysoké míře solidarity. U jednotlivých členů byla patrná ochota přizpůsobit se stávající situaci a vytvořit s členy znovusložené rodiny dobré vztahy (Braithwaite et al., 2001).

Druhým scénářem je scénář dlouhotrvající (prolonged). $\mathrm{V}$ rámci těchto rodin se pocit ,jsme rodina“ objevoval většinou velmi postupně a po delší době. Na začátku vývoje těchto znovusložených rodin byla popisovaná velmi malá míra solidarity. Jednotliví členové se necítili př́liš dobře a byli skeptičtí vůči nové rodině. Míra pocitu ,jsme rodina“ byla na začátku velmi nízká. Tyto rodiny je ovšem možné popsat jako flexibilní a adaptabilní, ochotné přizpůsobit se nové situaci. Oproti rodinám se zrychleným scénářem se liší tyto rodiny tím, že se nesnažily být „tradiční“ rodinou, ale naopak vytvářely vlastní definici toho, co to znamená být rodina. Postupně narůstala důvěra mezi jednotlivými členy rodiny, míra solidarity a přijetí. Komunikace se stávala otevřenější. Na konci výzkumu bylo možné tyto rodiny popsat jako relativně spokojené (Braithwaite et al., 2001).

Třetím typem scénáře je scénář upadající (declining). Typická pro tyto rodiny byla vysoká míra počátečního pocitu ,jsme rodina“, která se ale postupně snižovala. Těchto rodin byly ovšem pouze 3,5 \% v rámci výzkumu. Na počátku se objevovala vysoká očekávání, těšení se na rodinný život, která ale postupně klesala a začala se objevovat naopak úzkost a vysoká míra konfliktů, což zabránilo rozvoji solidarity a pocitu ,jsme rodina“. Konflikty byly spojené zejména s pokrevním poutem mezi jednotlivými členy 
a mezigeneračními rozdíly. Jednotliví členové nebyli schopni se vyrovnat s novými rolemi a často kritizovali chování ostatních členů. Na konci byla patrná beznaděj a vysoká nespokojenost s rodinou (Braithwaite et al., 2001).

Čtvrtým scénářem byl scénář stagnující (stagnating). Jednotliví členové se často cítili „být hozeni“ do rodiny a tlačeni do toho stát se rodinou, což zvyšovalo odpor jednotlivých členů $\mathrm{k}$ celé rodině. Typická byla nestabilita a nesplněná očekávání v rámci rodiny. Objevovaly se časté konflikty, které ještě více narušovaly již existující vztahy. Časté bylo to, že děti nesnesly své rodiče, a to jak vlastní, tak nevlastní zejména kvůli tomu, že na ně nebrali ohled při důležitých rozhodnutích. Pocit ,jsme rodina“ byl stagnující na velmi nízké úrovni a jednotliví členové byli v rodině nespokojeni (Braithwaite et al., 2001).

Poslední scénáŕ byl pojmenovaný jako vysoce turbulentní (high-amplitude turbulent). Tyto rodiny byly charakterizovány vysokou rozmanitostí, nestabilitou a nepředvídatelností. I zde se objevovala nereálná očekávání od nově vznikající rodiny, která doprovázela nespokojenost. Členové rodiny se často cítili být zrazeni a vůči novým členům rodiny vykazovali nedůvěru. Velmi nízká solidarita se objevovala mezi partnery, kteř́ nebyli jednotní ve svých rozhodnutích a řešení konfliktů. Vysoká míra konfliktů byla doprovázena snahou vyhnout se jakékoli konfrontaci (Braithwaite et al., 2001).

Kvalitativní studie kolektivu autorů Kellas et al. (2014) se zabývala 80 př́iběhy nevlastních dětí o jejich znovusložené rodině. Autoři této studie identifikovali celkem pět typů př́běhů a v souvislosti s tím zkoumali, kde byly děti nejspokojenější. Nejčastější typ př́iběhu byl „náhlý příběh“ (sudden story), kdy vznik znovusložené rodiny byl popisován jako rychlý, spontánní a jen s minimem komunikace. Děti vznik tohoto typu rodiny popisovaly jako př́lišs rychlý, tajný a také uzavřený, bez velkého plánování, a aniž by to dospělí v rodině s dětmi nějak probírali. Dalším typem příběhu o vzniku znovusložené rodiny byl „temný prríběh“ (dark-sided). Zde byl vznik znovusložené rodiny komplikovaný, doprovázený často pomluvami, konflikty, odhalením nevěry, finančními problémy aj. Dalším typem byly „příběhy ambivalentní“ (ambivalent), pro které byly typické protichůdné emoce. Typické zde bylo, že začátky vzniku znovusložené rodiny byly dobré, ale komplikované neshodami mezi rodiči po rozvodu. Předposledním typem př́iběhu o vzniku znovusložené rodiny byl ,idealizovaný typ“ (idealized), který byl popisovaný jako bezproblémový a rodina byla popisovaná jako skutečná rodina. Tento typ vzniku byl doprovázen pozitivními emocemi a pocity př́slušnosti k rodině. Poslední typ př́iběhu byl „příběh přírůstkový“ (incremental). Vznik znovusložené rodiny byl zde popisován jako plánovaný, organizovaný. Dospělí vše sdíleli s dětmi a nedocházelo zde k tajemstvím. Autoři této studie zjistili, že pokud byl vznik znovusložené rodiny doprovázen pozitivními emocemi a od počátku se mezi členy objevovala vřelost a blízkost, byly děti $\mathrm{v}$ těchto rodinách spokojenější než $\mathrm{v}$ těch, kde vznik byl doprovázen spíše negativními emocemi (Kellas et al., 2014).

Výzkumy se v minulosti hodně zaměřovaly na jednotlivé typy vztahů ve znovusložených rodinách (matka-děti, nevlastní otec-nevlastní děti,...), ale je velmi málo známo o tom, jak vzájemně spolu jednotlivé vztahy interagují, jak se ovlivňují a jakým způsobem ovlivňují procesy uvnitř znovusložených rodin. Jensen (2017) se ve své studii zaměřil na tyto nedostatky ve výzkumu a analyzoval data od celkem 1182 adolescentů, kteří žili ve znovusložené rodině s vlastní matkou a nevlastním otcem. Výsledky této studie ukázaly, že znovusložené rodiny lze rozdělit na 4 kategorie $v$ závislosti na tom, jaké interakce a mezi jakými členy jsou klíčové. 
První kategorii tvoří „,rodiny zahrnující všechny“ (inclusive pattern), pro kterou jsou typické velmi dobré vztahy uvnitř rodiny, ale zároveň dění v této rodině vysoce ovlivňuje vztah s neresidenčním otcem. Tento typ rodin se zaměřuje hlavně na podporu osobní pohody a spokojenosti dětí. Zároveň je ale pro tuto kategorie typické kratší trvání v porovnání s ostatními kategoriemi. Pro tyto rodiny je typický i vyšší finanční př́ijem. Další kategorí jsou „,rodiny orientované na vztahy uvnitřr“ (residence-centered pattern), pro kterou jsou typické vysoce pozitivní vztahy s residenčními členy (tj. těmi, s kterými je sdílena domácnost). Tyto rodiny jsou považovány za vysoce integrované a přizpůsobivé. Vlastní otcové, kteří v této domácnosti nežijí, nemají vliv na dění uvnitř rodiny. Třetí kategorií jsou „nešt’astné rodiny“ (unhappy pattern), pro kterou jsou typické konflikty mezi partnery/manžely, které mohou být i důsledkem nízkých finančních př́íjmů těchto rodin. Děti se v těchto rodinách mohou cítit nepř́ijemně a mohou tíhnout spíš k druhému biologickému rodiči, se kterým ovšem nežijí. Poslední kategorií jsou rodiny, kde došlo k odpojení v rámci vztahu rodič-dítě (parent-child disconnection). I v této kategorii se mohou objevovat konflikty či boj o zdroje napříc různými vztahy mezi členy rodiny. Děti se zde špatně přizpůsobují nové rodině. To může vést $\mathrm{k}$ napjatým vztahům mezi dětmi a matkou či mezi dětmi a nevlastním otcem (Jensen, 2017).

\section{Role vlastní matky ve znovusložené rodině a její vztah $k$ dětem}

Z longitudinálního výzkumu trvajícího 10 let, kterého se účastnilo celkem 60 rodin, vyplývá, že vztahy dětí a rodičů (obecně) jsou po rozvodu a po založení znovusložené rodiny nestabilní. Na rodičovství po rozvodu má přitom vliv mnoho faktorů - počet dětí v rodině, finance, vztah mezi biologickými rodiči, př́istup a zájem nevlastního rodiče. Autoři této studie ovšem uvádějí, že změny v rámci rodičovství jsou odrazem všech věcí, které musí rodič po rozvodu zvládnout a se kterými se musí vyrovnat (Wallerstein \& Lewis, 2007).

Role matky je ve znovusložené rodině, stejně jako v ostatních typech rodin, klíčová (Němcová, 2018). Dle některých autorů dokonce není možné porozumět dynamice této rodiny, aniž bychom pochopili, jakou roli zde matka zastává (Ganong \& Coleman, 2004). Matky ve znovusložených rodinách mají specifické úkoly. Musí pracovat na vztahu s partnerem, zároveň musí plnit rodičovskou funkci, a i nadále mají rozvíjet vztah se svými dětmi. Současně musí napomáhat při vytváření vztahu mezi svými dětmi a nevlastním otcem (Němcová, 2018; Pryor, 2008). Z longitudinálního výzkumu trvajícího 25 let, kterého se účastnilo 60 rodin, vyplývá, že po rozvodu jsou matky pro své děti méně dostupné v prŕípadě potřeby a že se matky o děti méně zajímají. Asi $1 / 3$ matek se zaměřila na dosažení ekonomické nezávislosti a navázání nového partnerského vztahu. To může mít poté samozrrejmě dopad na osobní pohodu dětí, což ukazují i výsledky této studie, nebot' u dětí se v důsledku toho objevilo problémové chování, které bývá považováno za jeden z indikátorů osobní pohody. Problémové chování ovšem ustoupilo, když se matky opět více zaměřily na rodinu, výchovu a péči o děti (Wallerstein, Lewis \& Rosenthal, 2013). Dle jiné studie (Wallerstein \& Lewis, 2007) matky dokonce často vnímají, že nedávají dětem tolik pozornosti, ale zároveň to nedokážou vzhledem k okolnostem a důsledkům rozvodu změnit. Některé matky se naopak zaměřily pouze na nejmladší dítě, které z jejich hlediska potřebovalo nejvíce péče, nebo na to dítě, které dávalo najevo, že matku potřebuje. Dle 
této studie si byly matky nejbližší s dětmi, které jim nejvíce pomáhaly, což byly nejčastěji nejstarší dcery (Wallerstein \& Lewis, 2007).

To, jak je rozvod náročný, značí i to, že pouze polovina matek v jiné studii se dovedla o děti starat a pečovat o ně tak jako před rozvodem. Některé matky se kvůli tomu vzdaly kariéry a upozadily navázání jiného intimního vztahu před péčí o děti. Jiným matkám napomohlo to, že se znovu provdaly, díky čemuž získaly finanční a emoční podporu, ačkoli se objevovaly konflikty mezi nevlastním otcem a dětmi. Matky, které se znovu provdaly, se tak o děti staraly stejně dobře jako v prvním manželství, ale s dětmi si nebyly již tolik blízké (Wallerstein, Lewis \& Rosenthal, 2013).

Tomu, jak matky ve znovusložených rodinách vnímají svoji roli, se věnovala kvalitativní studie, které se účastnilo celkem 24 matek (Weaver \& Coleman, 2010). Matky samy sebe vnímají hlavně jako prostředníka mezi dětmi a nevlastním otcem. $V$ prŕpadě, že mezi nevlastním otcem a dětmi vzroste míra konfliktů, matky bývají na straně dětí, přičemž vičč nim zaujímají protektivní postoj a zastávají určité speciální role, kterými mohou ovlivňovat osobní pohodu členů rodiny. Těmito rolemi jsou ochránce (defender), vrátný (gatekeeper), mediátor (mediator) a interpretující (interpreter). Role ochránce spočívá v ochraně dětí před jakýmkoli nebezpečím, a to i ze strany nevlastního otce, tj. matčina partnera. Matky rovněž naplňují roli vrátného, přičemž lze říct, že tato role spočívá v monitorování a sledování kontaktu a vztahu nevlastního otce s dětmi. Role mediátora spočívá v tom, že matky fungují jako prostředník mezi nevlastním otcem a dětmi a snaží se pomáhat s urovnáváním konfliktů mezi nimi. Poslední role interpretujícího hodně souvisí s rolí předchozí, nebot' pokud se matky snaží urovnávat konflikty mezi nevlastním otcem a dětmi dělají to často tak, že vysvětlují jednotlivým členům rodiny hledisko ostatních (Němcová, 2018; Weaver \& Coleman, 2010). V př́padě, že by se matka při konfliktu postavila na stranu nevlastního otce, vnímají to děti často jako ztrátu loajality a závazku ze strany matky vůči sobě. To může poté narušit vztah dítěte s matkou (Cartwright, 2005).

Zajímavé jsou výsledky studií, které ukazují, že po vytvoření znovusložené rodiny dochází ke změnám ve vztahu matky a dětí. Matky krátce po utvoření znovusložené rodiny vykazují více problémů $\mathrm{v}$ rámci výchovy dětí, prričemž u dětí se zároveň vyskytuje ve větší míŕe problémové chování (Bray, 1999; Bray \& Berger, 1993). Podle longitudinální studie z 90. let dochází mezi matkou a dětmi krátce po vytvoření znovusložené rodiny ve větší míře ke konfliktům a matky ve vztahu s dětmi vykazují více negativity, což samožrejmě může negativním zpo̊sobem ovlivňovat osobní pohodu dětí. Tato longitudinální studie rovněž ukázala, že po dvou letech soužití znovusložené rodiny se tyto problémy již neobjevují (Hetherington \& Clingempeel, 1992). Zvýšená míra konfliktů mezi rodiči a dětmi ve znovusložených rodinách může být reakcí dětí na množství konfliktů mezi rodiči a to, jak vlastními, tak nevlastními (Dunn, O'Connor \& Cheng, 2005). V novější studii (O'Connor et al., 2006), zabývající se rozdíly ve vztazích mezi dětmi a rodiči v různých typech rodin, které se účastnilo celkem 404 dětí ze 171 rodin, bylo rovněž zjištěno, že vztah matek a dětí ve znovusložených rodinách se liší od vztahu mezi matkami a dětmi $\mathrm{v}$ jiných typech rodin. Autoři hovoří o odlišném př́stupu matek ke svým biologickým dětem v rámci výchovy, který ovšem nepřipisují samotnému vzniku znovusložené rodiny a zvýšené úrovni stresu, ale běžným procesům vývoje rodiny a dětí. Thomson, Mosley, Hanson a McLanahan (2001) zjistili, že děti, jejichž matky po rozvodu navázaly nový vztah, hodnotí svůj vztah s matkou jako lepší v porovnání s dětmi, jejichž matky nový 
vztah nenavázaly. Zároveň se ovšem podle této studie objevuje více konfliktů mezi matkami a biologickými dětmi. Čigášová (2017) uvádí, že vztah mezi biologickým rodičem a dítětem se po utvoření znovusložené rodiny ne vždy změnil a často byl tento vztah s biologickým rodičem považován za stejný i po vytvoření znovusložené rodiny. Ke zhoršení vztahu s matkou může dojít $\mathrm{v}$ případě, že se dítě nesmíŕí s rozpadem rodiny původní (Čigašová, 2017).

Poměrně nekonzistentní jsou výsledky výzkumů týkající se otázky, zda dochází u matek po rozvodu a zejména po vytvoření znovusložené rodiny ke změně $\mathrm{v}$ rámci monitorování a kontrolování chování dětí. Monitorování a kontrolování dětí je považováno za jednu z dimenzí výchovného stylu, která může ovlivňovat osobní pohodu dětí. Kim, Hetherington a Reiss (1999) zjistili, že matky ve znovusložených rodinách vykazují vučči svým dětem, respektive synům, větší míru kontroly a monitoringu jejich chování v porovnání s matkami z rodin vlastních. Výsledky jiné studie ovšem poukazují na to, že kontrola chování dětí je vyšší v rodinách vlastních, zatímco v rodinách znovusložených míra kontroly a monitoringu chování dětí klesá, stejně jako klesá míra přijetí. Matky ve znovusložených rodinách také dle výsledků studií používají méně fyzických trestů či na děti méně křič́i (Thomson et al., 2001; Fisher et al., 2003; Leidy et al., 2011). Dle studie kolektivu autorů Leidy et al. (2011) se rodiče ve znovusložených rodinách rovněž méně zapojují do aktivit dětí. Matky jsou celkově vi̊či dětem ve znovusložených rodinách více odmítavé, u otců klesá míra přijetí. Existuje několik možných vysvětlení, proč tyto studie nedocházejí $\mathrm{k}$ jednotným výsledkům. Jedním z možných vysvětlení je, že některé studie tuto problematiku posuzují z pohledu matek, zatímco jiné z pohledu dětí. Možným vysvětlením může být rovněž to, že výzkumníci často nezohledňují dobu, po kterou je znovusložená rodina vytvořena (Ganong \& Coleman, 2004).

\section{Nevlastní otec a jeho vztah s dětmi v rodině}

Stejně jako matky čelí nevlastní otcové poměrně velké výzvě, kdy musí na pozadí nově utvářené rodiny navázat vztah s nevlastními dětmi. Přitom ovšem děti mají silný vztah s matkou, tj. partnerkou nevlastního otce, a mají své zvyky, do kterých se musí nevlastní otec pokusit začlenit. Postoj nevlastního otce $\mathrm{k}$ dětem může být velmi různorodý. Někteří nevlastní otcové se na tuto roli těší, zatímco jiní mají obavy z odmítnutí a někteří se nechtějí jakkoli zapojovat do interakce s nevlastními dětmi a podílet se na jejich výchově (Ganong \& Coleman, 2004; Matoušková, 2017; Němcová, 2018; Pryor, 2008). Někteří autoři dokonce považují rozvinutí dobrého a pozitivního vztahu mezi dětmi a nevlastním otcem za klíčový úkol znovusložené rodiny (Ganong et al., 2019). Z kvalitativní studie, které se účastnilo 12 nevlastních rodičů, vyplývá, že nevlastní rodiče si mohou být často nejistí ve své roli a role nevlastního rodiče jim zároveň není dost jasná (Felker et al., 2002). Mnohem těžší je v prrípadě nevlastních otců definovat jejich roli, když neresidenční otec je vysoce zapojen do péče o děti (Gold \& Adeyemi, 2013).

Dle kvalitativní studie, které se účastnilo 21 nevlastních otců, lze nalézt 4 základní postoje k roli nevlastního otce. Prvním z nich je postoj ,asistujícího rodiče“ (asistant parent), který je charakteristický tím, že tito nevlastní otcové jsou vůči nevlastním dětem zpočátku velmi milí, kamarádští, postupem času ovšem tato snaha upadá. Tito nevlastní otcové jsou do výchovy zapojeni jen velmi málo, a to i vzhledem k vysoké aktivitě obou 
biologických rodičů. Dalším postojem je postoj „replikace rodiny“ (replication family), kdy se neresidenční rodič neangažuje v péči o dítě, a role nevlastního otce je tak primárně rodičovská s typickým požadavkem na dodržování disciplíny. Tito nevlastní otcové si ovšem zároveň uvědomovali, že př́lišná autoritativnost a dodržování disciplíny, které neodpovídá emoční blízkosti s nevlastním dítětem, by mohlo vztah s nevlastním dítětem ohrozit. Třetím postojem je postoj „třetího rodiče“ (third parents), kdy se nevlastní otcové necítí být primárně rodičem, ale spíše součástí jakéhosi týmu, který se podílí na výchově dítěte. Toto je typické i pro čtvrtý postoj, kterým je postoj „rozšířená rodina“ (extended family), který se ovšem liší tím, že nevlastní otec má blízký vztah s neresidenčním otcem (Svare, Jay \& Mason, 2004).

Vytváření vztahu mezi nevlastním otcem a dětmi může být zpočátku složité, nebot' děti mohou nevlastního otce vnímat jako zdvořilého vetřelce (Hetherington \& Clingempeel, 1992) nebo ho mohou vidět jako soupeře, který narušuje vztah $\mathrm{s}$ jejich matkou a bere jim matčinu pozornost (Sobotková, 2001). Čigášová (2017) uvádí faktory, které se pojí s přijetím či naopak nepřijetím nevlastního rodiče. S nepřijetím nevlastního rodiče jsou spojené faktory jako negativní pohled dítěte na utvoření partnerského vztahu a na chování nevlastního rodiče. $\mathrm{S}$ přijetím nevlastního rodiče může naopak souviset smíření s rozpadem původní rodiny, postupnost při navazování vztahu s nevlastním rodičem a pozitivní vnímání chování nevlastního rodiče. Čigašová (2017) ovšem uvádí, že mezi těmito faktory a přijetím či nepřijetím nevlastního rodiče nebyla prokázána kauzalita. Ganong a Coleman (2004) rozlišují tři typy nevlastního otce podle toho, jak se chovají vůči nevlastním dětem na začátku vytváření vztahu a později. Prvním z nich jsou ti, kteří se neustále snaží být pro děti kamarády, nejen na začátku (tzv. continuous affinity-seeker). Druhým typem jsou ti nevlastní otcové, kteří se snaží s dětmi zpočátku navázat kamarádský vztah, snaží se jim zalíbit, ale postupem času zaujímají rodičovskou roli (tzv. early affinity-seekers). Třetí skupinou jsou ti nevlastní otcové, kteří se př́liš nesnaží nevlastním dětem zalíbit (tzv. nonseekers). Nejlepší a zároveň nejstabilnější vztah s nevlastními dětmi mají nevlastní otcové, kteří patř́ do první skupiny (tzv. continuous affinity-seekers) (Ganong \& Coleman, 2004). Naopak ti nevlastní rodiče, kteří se od samého počátku snaží zaujmout otcovskou roli, se mohou u nevlastních dětí setkat s odporem. Děti se totiž mohou domnívat, že nevlastní otec chce plně zaujmout místo jejich vlastního otce, který s nimi už nežije (Ganong et al., 1999). Ti nevlastní otcové, kteří zastávají názor, že je důležité u dětí dodržování disciplíny, jsou často mnohem starší než jejich partnerky a tento postoj zastávají zejména vůči chlapcům. $\mathrm{V}$ důsledku toho jsou poté vztahy dětí s nevlastním otcem vyhrocené (Wallerstein \& Lewis, 2007).

Matoušková (2017) ve své rigorózní práci uvádí, že pro nevlastní otce mohou být frustrující otázky výchovy, a to z toho důvodu, že nevlastní otcové nemají autoritu, kterou mají biologičtí rodiče a zároveň mají pohled na výchovu dětí jiný než jejich partnerka. Zároveň se nevlastní otcové mohou cítit nejistí právě kvůli kompetencím v oblasti výchovy, kdy si nevlastní otcové nejsou jisti tím, co vše si v rámci výchovy mohou dovolit. Jednou z nepř́ijemných věcí, s kterou se musí nevlastní otcové potýkat, je možná rivalita s biologickým otcem dětí. Nevlastní otcové zároveň hovořili o tom, že získali hezký vztah s partnerkou či že vztah s nevlastním dítětem jim nahrazuje a vynahrazuje vztah s dítětem vlastním.

Dle studie autorů Wallerstein a Lewis (2007) nevlastní otcové často preferují některé nevlastní dítě, přičemž to dávají najevo většinou od samého počátku. Ačkoli může být 
vytváření vztahu mezi dětmi a nevlastním otcem komplikované, bývá tento vztah dle některých studií ve většině př́ípadů pozitivní, ačkoli se zcela nevyrovná vztahu, který je mezi dětmi a jejich vlastním otcem. Nevlastní otcové se rovněž nezapojují tolik do aktivit dětí jako otcové vlastní (Hofferth et al., 2007). Z pohledu matek vykazují nevlastní otcové stejnou či dokonce větší míru pomoci při výchově dětí v porovnání s otci vlastními (Berger et al., 2008). Mnoho dětí ve znovusložených rodinách má dobrý a vřelý vztah jak s otcem vlastním, tak nevlastním. To vyplývá ze studie, které se účastnilo 189 adolescentů (White \& Gilbreth, 2001). Dokonce i v průběhu času a toho, jak děti dospívají, zůstává ve většině př́padů vztah mezi nevlastním otcem a dětmi pozitivní (King \& Lindstrom, 2016) a to i přesto, že nevlastní otcové mají často menší pochopení pro změny v chování dětí, které se objevují právě v období puberty (Wallerstein \& Lewis, 2007).

Lze říct, že nevlastní rodiče obecně investují do nevlastních dětí méně (čas, peníze, pozornost apod.) v porovnání s rodiči vlastními. Je ale nepravděpodobné, že by do nevlastních dětí neinvestovali vůbec, nebot' investice se jim poté zpětně vyplatí v rámci partnerského vztahu a jeho rozvoje (Tifferet, Jorev \& Nasanovitz, 2010). Vztah nevlastního otce s nevlastními dětmi je přitom ovlivněn právě tím, kolik nevlastní otec do tohoto vztahu investuje (pozornost, trávení času s dětmi apod.), přičemž kvalita tohoto vztahu poté ovlivňuje právě stabilitu partnerského/manželského vztahu ve znovusložené rodině (Ganong et al., 2019; Petren et al., 2019). Pokud se nevlastní otcové méně zapojují do aktivit s dětmi, nemají s nimi navázaný blízký vztah a nepodporují matku při výchově, je zde větší pravděpodobnost, že se znovusložená rodina rozpadne (Petren, Garneau-Rosner \& Yildirim, 2018).

Významnou roli při vytváření vztahu mezi nevlastním otcem a dětmi hraje vztah matky a dětí ve znovusložené rodině (Cartwright, 2005; Dunn et al., 2004; King, 2009; King, Thorsen, \& Amato, 2014). Čigašová (2017) uvádí, že pokud byl vztah s matkou vnímán stejně před i po vytvoření znovusložené rodiny, bylo pro děti snazší přijmout nevlastního rodiče a navázat s ním vřelý vztah. Pokud děti matku vnímají jako zodpovědnou a dostupnou v př́padě potřeby, znamená to pro ně více stability během náročného období přechodu z jedné rodiny do nové. Pokud jsou matky zároveň otevřené v komunikaci ohledně nevlastního otce, nejsou děti tolik rozzlobené na nevlastního otce, což může poté napomoci při navazování vztahu s ním. Důležité zároveň je, aby se matka s nevlastním otcem shodli v otázkách výchovy, což poté také pozitivně ovlivňuje vytváření vztahu mezi nevlastním otcem a dětmi (Cartwright, 2005; Jensen \& Shafer, 2013; King, Amato \& Lindstrom, 2015). Mnozí výzkumníci předpokládali, že vztah nevlastního otce s dětmi může být ovlivněn vztahem, který mají děti se svým vlastním otcem. Tento předpoklad se ale zatím nepotvrdil (King, 2009; King, Amato \& Lindstrom, 2015).

Velmi důležité je si uvědomit, že pro vytvoření dobrého vztahu s nevlastním otcem není důležitá pouze snaha nevlastního otce, ale také snaha dětí v rodině (Ganong \& Coleman, 2004). Mnoho dětí se přitom do vztahu s nevlastním otcem aktivně zapojuje a snaží se, o čemž svědčí jak frekvence kontaktů, sdílených aktivit, tak i to, že si děti s nevlastním otcem povídají o důležitých věcech jako je škola (King et al., 2014). Ganong, Coleman a Jamison (2011) na základě kvalitativního výzkumu zjistili, že snaha dětí a míra, do jaké se děti snaží navázat dobrý vztah s nevlastním otcem, souvisí s tím, jaké mají děti hodnotící soudy o nevlastním otci a jeho prrínosu pro rodinu. Tyto soudy jsou přitom ovlivněny zejména tím, co si myslí matka a další blízcí příbuzní. Lze říct, že dospívající děti častěji zpochybňují nevlastního rodiče a vyvolávají konflikty (Wallerstein \& Lewis, 2007). 
Poněkud snazší mohou mít situaci při navazování vztahu s nevlastními dětmi ti otcové, kteří mají ve znovusložené rodině i své vlastní děti, o které pečují. V takovém případě vykazují otcové větší míru chování spojeného s otcovskou rolí i vůči nevlastním dětem a zároveň s nimi lépe navazují vztahy (Marsiglio, 1992). Úskalím ovšem může být to, když se nevlastní rodič ve znovusložené rodině zaměří pouze na své biologické děti, zatímco ty nevlastní upozad'uje. To většinou vede k tomu, že rodič očekává od nevlastních dětí až př́lišnou poslušnost. Nevlastní rodičovství se tak stává mnohem obtížnější a děti nevlastního rodiče spíše odmítají. Toto zaměření na biologické děti může vést ke kritice i ze strany partnera, čímž může být negativně ovlivněna i spokojenost v rámci partnerského vztahu (Jensen, Shafer \& Larson, 2014).

Výzkumně byly spíše zkoumány vztahy mezi nevlastním otcem a dětmi, zatímco nevlastní matky a jejich vztahy s nevlastními dětmi bývají často upozad'ovány. Nevlastní matky mají těžší situaci, nebot’ se od nich očekává, že i když nejsou vlastními matkami dětí svého partnera, budou zastávat mateřskou roli a svědomitě pečovat o děti (Ganong \& Coleman, 2004). Sobotková (2001) mluví o tzv. mýtu okamžité lásky, podle kterého se očekává, že nevlastní matky budou mít okamžitě rády děti svého partnera a budou je brát jako vlastní. Vzhledem k tomu, že nevlastní matky o děti pečují, často jsou s nimi v kontaktu více než vlastní otec. Musí od dětí často proto vyžadovat disciplínu a dodržování pravidel, což může být $\mathrm{v}$ rozporu s chováním, které by pomohlo navázat s nevlastními dětmi vřelý vztah. Někteří autoři tvrdí, že matky, a to i ty nevlastní, jsou důležitým faktorem pro osobní pohodu dětí (Ganong \& Coleman, 2004).

Sobotková (2001) hovoří o tom, že nejistota ohledně nově získaných rolí může ohrozit identitu nevlastních matek. Nová role nevlastní matky může být často velmi ambivalentní a projevuje se nejistotou ohledně množství povinností, konkrétního jednání a naplňování těchto povinností, nejistotou týkající se toho, které očekávání má být naplněno dřive a také nejistotou spojenou s chováním a jeho důsledky na osobní, ale také rodinou pohodu. Nevlastní matky mají samy často potřebu definovat svoji roli ve vztahu k dětem.

Na základě kvalitativního výzkumu bylo zjištěno, že nevlastní matky mohou zaujmout trri základní postoje ohledně své role v domácnosti - „mateřství, ale ne role matky“ (mothering but not mother roles), „ostatní role“ (other-focused roles), „role outsidera“ (outsider roles). První postoj (mothering but not mother roles) spočívá v tom, že nevlastní matky se chovají mateřsky, ale necítí se být vůči nevlastním dětem matkami. Tyto nevlastní matky často svoji roli v domácnosti popisují ambivalentně, přičemž pocity nevlastní matky jsou často ovlivněny přítomností biologické matky dětí. V rámci druhého postoje (other-focused roles) nevlastní matky vidí svoji roli v zaměření se na potřeby ostatních, ale ne dětí. Tyto matky často fungují jako prostředník mezi svým partnerem a biologickou matkou partnerových dětí, přičemž domlouvají návštěvy, vyzvedávání dětí apod. V rámci posledního postoje (outsider roles) lze identifikovat dvě role. První z nich je, že nevlastní matky jsou zapojeny do dění v rodině, ale pouze na jejím okraji a nejsou například plně zapojeny do aktivit dětí a otce. Druhá role spočívá v tom, že matky se nepovažují za důležitého člověka v životě nevlastních dětí a nemají na ně žádný výrazný vliv. V tomto případě byl vztah dětí a nevlastní matky popisován jako nejméně blízký (Weaver \& Coleman, 2005). Z výzkumu, kterého se účastnilo asi 300 adolescentů, vyplývá, že většina z nich má dobrý a vřelý vztah jak s matkou vlastní, tak i nevlastní (King, 2007).

Nevlastní matky často berou jako prioritu jejich domácnost a životní styl, nikoli potřeby dětí. Nevlastní matky také upřednostňují to dítě, které se rychle přizpůsobí a se kterým 
vychází. Ty nevlastní matky, které mají vlastní děti, upřednostňují to nevlastní dítě, které dobře vychází s jejími vlastními dětmi (Wallerstein \& Lewis, 2007).

\section{Vztah dětí s neresidenčním rodičem}

Neresidenční rodiče, kteří po rozpadu původní rodiny nežijí společně s dětmi, jsou dle Stewarta (1999) spíše rodiči pro trávení volného času. Pokud mluvíme o neresidenčním rodiči, mluvíme ve většině prrípadů o otci dětí. Ti jsou se svými dětmi po rozpadu původní rodiny v kontaktu méně často. Nicméně důležitější je kvalita vztahu mezi otcem a dětmi. Pro neresidenční rodiče je mnohem náročnější zhostit se své rodičovské role, nebot's dětmi nejčastěji tráví pouze limitovaný čas. I z toho důvodu někteří autoři mluví o tom, že neresidenční rodiče mají na děti menší vliv, než měli předtím (Ganong \& Coleman, 2004). Děti přitom samozřejmě neresidenčního rodiče potřebují (Schwartz \& Finley, 2009). Poněkud lépe jsou na tom v tomto př́padě biologické matky, které s dětmi nežijí, nebot' jsou s dětmi častěji v telefonickém kontaktu, častěji využívají elektronické komunikace a děti u nich častěji přespávají v porovnání s biologickými neresidenčními otci (Gunnoe \& Hetherington, 2004). Frekvence kontaktu se přitom ukazuje jako velmi důležitý faktor ovlivňující vztahy dětí a neresidenčních matek (King, 2007).

Je nutné si uvědomit, že vztah s druhým biologickým rodičem, se kterým ovšem dítě nežije, je pro dítě rovněž důležitý. Edwards (2002) tvrdí, že udržení vztahu dítěte s biologickým neresidenčním rodičem je důležité pro zachování stability dítěte ve znovusložené rodině. Když dítě udržuje vztah s neresidenčním rodičem, je propojena jeho minulost se současností. I tento vztah tak ovlivňuje osobní pohodu dítěte. Udržení tohoto vztahu může být po vzniku znovusložené rodiny náročnější a pro dítě stresující, nebot' se zároveň musí snažit vytvořit vztah s rodičem novým, nevlastním. Děti jsou tak vždy mezi těmito dvěma vztahy (Jensen, Shafer \& Holmes, 2015). Vztah neresidenčního rodiče s dítětem a míra, v jaké se neresidenční rodič podílí na péči a výchově dítěte, je významně ovlivněna vztahem mezi oběma biologickými rodiči dítěte. Pokud je tento vztah dobrý a nedochází zde ke konfliktům, neresidenční rodič se více podílí na péči o děti, a i nadále s dítětem rozvíjí vřelý vztah (Ahrons, 2007; Fagan \& Palkovitz, 2007).

Otcové se po rozpadu původní rodiny mohou cítit být pro své děti nepotřební a zároveň je pro ně z finančních a časových důvodů mnohem těžší podílet se na výchově dětí (Ahrons, 2007; Russell et al., 2016). Pokud dojde k odcizení dítěte s biologickým otcem po rozvodu, má toto odcizení negativní dopad i na vztah s prarodiči z otcovy strany, nevlastní matkou a nevlastními sourozenci z otcovy strany (Ahrons, 2007; Němcová, 2018). V rámci studie White a Gilbreth (2001), které se účastnilo celkem 189 dětí vyrůstajících ve znovusložené rodině s matkou a nevlastním otcem, bylo zjištěno, že $2 / 3$ těchto dětí mělo velmi dobrý vztah se svým biologickým otcem a pouze velmi málo dětí s biologickým otcem neudržovalo žádný vztah. Ze stejné studie vyplynulo, že vztah dětí s biologickým neresidenčním otcem není ovlivněn vztahem dětí a matky.

Wallerstein, Lewis a Rosenthal (2013) zjistili, že v rodinách, kde byly 3 a více dětí, bylo pro otce mnohem těžší udržet si pěkný vztah se svými dětmi (povedlo se to 3 ze 16 otců). Vztah s dětmi bylo pro neresidenčního otce rovněž těžší si udržet v př́padě, že založil i on novou rodinu a s novou partnerkou měl další dítě. Toto dítě bylo často otcem preferované, což se projevovalo i tím, že mu kupoval dražší dárky. Rovněž se ukázalo, že neresidenční 
otcové mohou upřednostňovat po rozvodu to dítě, s kterým sdílí nějakou zálibu nebo které je s nimi ochotné trávit čas. Otcové rovněž vnímali jako snazší udržet si pěkný vztah s dítětem, které bylo mladší, zatímco s adolescentním dítětem vnímali udržení vztahu jako náročnější.

Přesto lze říct, že vztahy dětí s neresidenčním otcem mohou být velmi různorodé a celkově lze říct, že nejsou zcela předvídatelné. Blízký vztah otce a dětí před rozvodem není prediktorem a zárukou dobrého vztahu i po rozvodu. Vztah je ovšem ovlivněn vztahem nové otcovy partnerky/nevlastní matky k dětem z prvního manželství, a tím, jestli je vnímá jako potenciální ohrožení jejich vztahu. Lze říct, že ti otcové, kteří i po rozvodu měli dobré vztahy se svými dětmi a nadále je rozvíjeli, měli podporu od své nové partnerky, která ovšem často neměla vlastní děti (Wallerstein \& Lewis, 2009). Některé partnerky mohou vztah neresidenčního otce s dětmi ovlivňovat i negativně, což může vést $\mathrm{k}$ tomu, že se neresidenční otec s dětmi odcizí. Otcové totiž většinou nezpochybňují postoj partnerky ohledně toho, co je důležité pro jeho biologické děti. Často s tím ale nejsou spokojeni (Wallerstein \& Lewis, 2007).

\section{Sourozenecké vztahy ve znovusložených rodinách}

Sourozenecké vztahy ve znovusložených rodinách jsou samy o sobě poměrně složité, nebot' se zde setkáváme kromě sourozenců vlastních (full-siblings), také se sourozenci nevlastními (stepsiblings) a polovičními (half-sibligs). Pokud mluvíme o vlastních sourozencích, jedná se o ty sourozence, kteří mají oba biologické rodiče společné. Poloviční sourozenci mají pouze jednoho biologického rodiče společného. Nevlastní sourozenci nemají společné biologické rodiče (Němcová, 2018).

Už samotný rozpad původní rodiny je pro děti zatěžující a ovlivňuje i sourozenecké vztahy. Dle studie, která byla provedena na reprezentativním vzorku, čítajícím asi 8500 účastníků, se mohou mezi sourozenci objevit ve zvýšené míre konflikty poté, co dojde $\mathrm{k}$ rozpadu rodiny $\mathrm{v}$ důsledku úmrtí jednoho z rodičů. Možným vysvětlením je to, že děti v rodině ztratí možnost podpory a sociální opory, kterou rodiče poskytují (Fuller-Thomson, 2000; Němcová, 2018). Z dlouhodobého hlediska lze ovšem říct, že sourozenci, kteří v dětství přišli o jednoho z rodičů, si jsou v dospělosti bližší v porovnání s těmi sourozenci, kteří o rodiče nepřišli (Mack, 2004). Rovněž rozvod a v jeho důsledku rozpad rodiny má vliv na sourozenecké vztahy. Významnou roli přitom hraje věk, ve kterém děti prožily rozvod rodičů (Riggio, 2001). Při rozvodu dochází často mezi rodiči ke konfliktům, které mohou souviset rovněž se zvýšenou mírou konfliktů mezi sourozenci, zvýšenou dominancí jednoho sourozence vůči druhému a rivality a zároveň mohou vést ke snížení vřelosti mezi sourozenci (Němcová, 2018; Stocker \& Youngblade, 1999). Vztahy sourozenců po rozvodu lze charakterizovat zvýšenou emoční intenzitou, která se projevuje jak již zmíněnou zvýšenou mírou konfliktů, tak i tím, že vztahy mezi sourozenci jsou vřelejší v porovnání se sourozenci, jejichž rodiče se nerozvádějí (Němcová, 2018; Sheehan et al., 2004). Ke konfliktům může mezi sourozenci docházet zejména v př́padě, že každý stojí na straně některého z rodičů (Grenwood, 2014). Zvýšenou míru konfliktů u sourozenců, jejichž rodiče se rozvedli, lze nalézt mezi sourozenci i v dospělosti, přičemž kvalita jejich vztahu není nijak jinak dotčena (Němcová, 2018; Poortman \& Voorpostel, 2009). Tyto změny (zvýšená míra konfliktů a vřelosti) popisují sami sourozenci, přičemž 
retrospektivně mluví o časově ohraničeném období, které netrvalo dlouho (Bush \& Ehrenberg, 2003). Ze strany starších sourozenců lze zaznamenat rovněž větší míru starostlivosti o mladšího sourozence (Němcová, 2018; Roth, Harkins \& Eng, 2014). Při porovnání vztahu mezi vlastními sourozenci z rodin původních a sourozenců, jejichž rodiče se rozvedli, bylo ve studii autorů Anderson a Rice z roku 1992 zjištěno, že sourozenci, jejichž rodiče se rozvedli, nevykazují takovou míru vřelosti jako sourozenci žijící v rodinách biologických. Stejný autor ale o několik let později ve své další studii došel k závěru, že se tyto vztahy nijak významně neliší (Anderson, 1999; Němcová, 2018). Vliv na sourozenecké vztahy ve znovusložených rodinách mohou mít také faktory jako finanční zdroje, jiný styl života v důsledku vytvoření nové rodiny, vztah mezi partnery, doba soužití sourozenců, vztah rodičů a dětí a rozdílný prŕistup rodičů k dětem ve znovusložené rodině (Henderson \& Taylor, 1999; Hetherington, 1989; Mekos, Hetherington \& Reiss, 1996; Němcová, 2018; Pryor, 2008).

Čigašová (2017) ve své diplomové práci realizovala kvalitativní výzkum, na jehož základě uvádí, že vztahy mezi sourozenci jsou ve znovusložených rodinách vnímány pozitivně, ale liší se mírou koheze, přičemž rozdíly nebyly vysvětlitelné na základě pokrevní př́buznosti. Pokud jde o měření kvality sourozeneckých vztahů ve znovusložených rodinách, jsou i v nejnovějších výzkumných studiích hojně citované výzkumy z 90. let a studie provedené krátce po roce 2000. Z těchto studií vyplývá, že mezi sourozenci vlastními se objevuje nejvyšší míra záporných aspektů (rivalita a konflikty) v porovnání se sourozenci nevlastními a polovičními (Anderson, 1999; Deater-Deckard, Dunn \& Lussier, 2002; Ganong \& Coleman, 1993; Němcová, 2018). Méně konzistentní jsou výsledky těchto studií týkající se pozitivních aspektů sourozeneckých vztahů (spolupráce, vřelost, empatie). Zatímco studie Ganong a Coleman (1993) poukazuje na to, že zároveň nevlastní sourozenci vykazují v porovnání s těmi vlastními a polovičními významně nižší míru pozitivních aspekti̊, v rámci studií autorů Deater-Deckard, Dunn a Lussier (2002) a Andersona (1999) nebyly žádné rozdíly v míře pozitivních aspektů naprŕíc různými sourozeneckými vztahy nalezeny (Němcová, 2018).

Sourozenci vlastní vykazují vůči sobě více rivality než sourozenci poloviční. Z evolučního hlediska lze tento fakt vysvětlit tím, že sourozenci poloviční žijí s oběma svými biologickými rodiči a nemusí soutěžit v takové míře o jejich pozornost jako sourozenci vlastní, kteří mají ve znovusložené rodině pouze jednoho biologického rodiče (Němcová, 2018; Tanskanen et al., 2016). Přesto lze ale říct, že vztahy polovičních sourozenců a sourozenců vlastních se od sebe navzájem tolik neliší (Němcová, 2018). Pokud spolu sourozenci poloviční vyrůstají od útlého dětství, jsou jejich vztahy velmi podobné, takřka identické jako vztahy mezi sourozenci vlastními (Danielsbacka \& Tanskanen, 2015). V souvislosti s polovičními sourozenci někteří autoři rovněž zmiňují, že tyto děti, jako společné děti partnerů/manželů ve znovusložené rodině, by měly mít na rodinu stmelující vliv. Tato hypotéza nebyla ovšem nijak výzkumně prozkoumána (Ganong \& Coleman, 2004; Němcová, 2018). Některé studie ovšem poukazují na negativní vlivy, které mohou mít poloviční sourozenci (rizikové, potenciálně závislostní chování či zvýšená míra úrazů) (Harcourt et al., 2015; Němcová, 2018; Tanskanen, Danielsbacka, \& Rotkirch, 2015).

Hyblerová (2011) se ve své diplomové práci zabývala vztahem nevlastních sourozenců ve znovusložených rodinách. S celkem 10 nevlastními sourozenci provedla skupinovou diskusi, během které se ukázalo, že se u respondentů objevila touha mít nevlastního sourozence stejného pohlaví, přičemž v sourozenci stejného pohlaví viděli potenciální větší míru 
opory. Do vztahu nevlastních sourozenců se mohou negativně promítat hádky mezi rodiči, prričemž se jednalo zejména o situace, kdy rodiče do svých sporů zatahovali právě i děti.

\section{Diskuse}

Zkoumání znovusložených rodin je zcela jistě téma, které je velmi citlivé jak pro děti, tak rodiče a které je nutné velmi dobře metodologicky a zejména eticky ošetřit. Jak již bylo zmíněno výše, je výzkum týkající se těchto rodin rovněž velmi náročný zejména kvưli složitosti a propojenosti vztahů uvnitř těchto rodin. To se samozřejmě odráźí i na kvalitě různých studií a jejich metodologickém řešení. Mnoho zahraničních studií je typických tím, že využívá velké národní reprezentativní vzorky. Zde je ovšem nutné podotknout, že takové studie, respektive primární sběr dat neprobíhal přímo za účelem zkoumání znovusložených rodin, ale za účelem jiným. Proto tyto studie usuzují na děje, vztahy a osobní pohodu členů znovusložených rodin spíše nepřímo z některých ukazatelů, které jsou $\mathrm{k}$ dispozici. Dalším metodologickým problémem, který se velmi často objevuje v různých studiích, je, že vztahy uvnitř rodiny jsou hodnoceny pouze $\mathrm{z}$ hlediska jednoho jejího člena, např. matky, která vypovídá o vztahu dětí a nevlastního otce. Vzhledem k tomu mohou být mnohé údaje a výsledky studií zkresleny, nebot' neznáme pohled těch členů rodiny, na které se studie př́imo zaměřily. Mnohem zajímavější, ale rovněž náročnější by samozřejmě bylo získat výpovědi všech členů rodiny a jejich pohledy posléze porovnávat. Za velmi př́nosné lze považovat longitudinální a kvalitativní studie na toto téma. Oba typy studií jsou samozrrejmě náročné, a proto je jich v porovnání se studiemi kvantitativního typu málo (Němcová, 2020).

Velmi dobře problematiku výzkumu znovusložených rodin hodnotí autoři Anderson a Greene (2013). Autoři pojednávají o tom, jakým způsobem je výzkumně přistupováno $\mathrm{k}$ těmto rodinám a zejména se zabývají tím, jak jsou výsledky jednotlivých studií interpretovány. Autoři vidí jako problém to, že jako referenční bod pro porovnávání znovusložených rodin jsou zvoleny rodiny biologické. Dle autorů tento referenční bod není zvolen vhodně, nebot' biologické rodiny neprošly rozpadem a není tak možné zjistit, zda rozdíly mezi rodinami biologickými a znovusloženými jsou dány skutečným typem rodiny, či rozpadem rodiny biologické. Právě kvůli tomu doporučují autoři longitudinální zkoumání a porovnávání rodiny před vznikem a po vzniku znovusložené rodiny. Teprve díky těmto studiím by bylo možné dle autorů zjistit, jaký vliv na vztahy, osobní pohodu a jednotlivé členy rodiny má vznik znovusložené rodiny (Anderson \& Greene, 2013; Němcová, 2020). Stejní autoři také poukazují na interpretaci výsledků studií, které se týkají zejména osobní pohody dětí ve znovusložených rodinách. Autoři tvrdí, že pokud je rozdíl při srovnání rodin znovusložených s jiným typem rodinného soužití signifikantní, je třeba se podívat i na konkrétní výsledky a zjistit, jak velký je skutečný rozdíl. Př́kladem může být interpretace metaanalýzy Amato (1994), kde lze učinit závěr, že děti ve znovusložených rodinách mohou být zvýšeně ohrožené problémovým chováním. Přesto ale 80 \% z nich nevykazuje dle této metaanalýzy žádné problémy. První interpretace tak může být zavádějící (Anderson \& Greene, 2013; Němcová, 2020).

Článek autorů Anderson a Greene (2013) je tak poměrně zásadním př́íspěvkem, který poukazuje na to, že znovusložené rodiny jsou často vnímány pouze negativně, což je zcela neoprávněné. Znovusložené rodiny jsou pouze jedním typem rodinného soužití. Nelze 
říct, že tyto rodiny jsou pouze „špatné“ a biologické rodiny jsou pouze „dobré“. Stejně jako mohou být napjaté vztahy v rodině znovusložené, mohou být napjaté vztahy i v rodině biologické. Stejně jako může biologická rodina tvořit bezpečné zázemí pro rozvoj dětí, může být rodina znovusložená také bezpečným zázemím pro rozvoj dětí. Výzkumně bychom se měli zaměřit na to, jakým způsobem může být při formování nové rodiny toto bezpečné zázemí vytvářeno a jakým způsobem mohou být vztahy uvnitř těchto rodin pozitivně ovlivněny. Tyto poznatky mohou být totiž skutečně velmi užitečné pro praxi rodinného a psychologického poradenství při práci s těmito rodinami (Němcová, 2020).

\section{LITERATURA}

Ahrons, C. R. (2007). Family ties after divorce: Long-term implications for children. Family Process, 46(1), $53-65$.

Amato, P. R. (1994). The implications of research findings on children in stepfamilies. In A. Booth \& J. Dunn (Eds.), Stepfamilies: Who benefits? Who does not? (81-87). Hillsdale, NJ: Erlbaum.

Anderson, E. R. (1999). Siblings, halfsiblings, and stepsiblings relationships in remarried families. In E. M. Hetherington, S. H. Henderson, \& D. Reiss (Eds.), Adolescent siblings in stepfamilies: Family functioning and adolescent adjustment. Monographs of the Society for Research in Child Development, 64(4), 101-126.

Anderson, E. R., \& Greene, S. M. (2013). Beyond divorce: Research on children in repartnered and remarried families. Family Court Review, 51(1), 119-130.

Anderson, E. R., \& Rice, A. M. (1992). Sibling relationships during remarriage. Monographs of The Society Research in Child Development, 57(2/3), 149-177.

Berger, L. M., Carlson, M. J., Bzostek, S. H., \& Osborne, C. (2008). Parenting practices of resident fathers: The role of marital and biological ties. Journal of Marriage and Family, 70(3), 625-639.

Braithwaite, D., Olson, L., Golish, T., Soukup, Ch., \& Turman, P. (2001). "Becoming a family": Developmental processes represented in blended family discourse. Journal of Applied Communication Research, 29(3), 221-247.

Bray, J. H. (1999). From marriage to remarriage and beyond: Findings from the Developmental issues in Stepfamilies research project. In E. M. Hetherington (Ed.), Coping with divorce, single parenting, and remarriage: A risk and resiliency perspective (253-271). Lawrence Erlbaum Associates Publishers.

Bray, J. H., \& Berger, S. H. (1993). Developmental issues in Stepfamilies research project: Family relationships and parent-child interactions. Journal of Family Psychology, 7(1), 7-90.

Bush, J., \& Ehrenberg, M. (2003). Young persons' perspectives on the influence of family transitions on sibling relationships: a qualitative exploration. Journal of Divorce \& Remarriage, 39(3-4), 1-35.

Cartwright, C. (2005). Stepfamily living and parent-child relationships: An exploratory investigation, Journal of Family Studies, 11(2), 267-283.

Claxton-Oldfield, S. (2000). Deconstructing the Myths of the Wicked Stepparent. Marriage \& Family Review, $30,51-58$.

Čigášová, K. (2017). Vztahy mezi členy nevlastnich rodin. Nepublikovaná diplomová práce, Univerzita Palackého v Olomouci, Česká republika.

Danielsbacka, M., \& Tanskanen, A. O. (2015). The association between unequal parental treatment and the sibling relationship in Finland: The difference between full and half - siblings. Evolutionary Psychology, 13(2), 492-510.

Deater-Deckard, K., Dunn, J., \& Lussier, G. (2002). Sibling relationships and social - emotional adjustment in different family contexts. Social Development, 11(4), 571-590.

Dunn, J. H., Cheng, H., O’Connor, T. G., \& Bridges, L. (2004). Children's perspectives on their relationships with their nonresident fathers: Influences, outcomes, and implications. Journal of Child Psychology and Psychiatry, 45(3), 553-566.

Dunn, J., O'Connor, T. G., \& Cheng, H. (2005). Children's responses to conflict between their different parents: Mothers, stepfathers, nonresident fathers, and nonresident stepmothers. Journal of Clinical Child and Adolescent Psychology, 34(2), 223-234. 
Edwards, R. (2002). Creating 'stability' for children in step-families: Time and substance in parenting. Children \& Society, 16(3), 154-167.

Fagan, J., \& Palkovitz, R. (2007). Unmarried, nonresident fathers' involvement with their infants: A risk and resilience perspective. Journal of Family Psychology, 21(3), 479-489.

Felker, J. A., Fromme, D. K., Arnaut, G. L., \& Stoll, B. M. (2002). A qualitative analysis of stepfamilies. Journal of Divorce \& Remarriage, 38(3-4), 125-142.

Fisher, P. A., Leve, L. D., O’Leary, C. C., \& Leve, C. (2003). Parental monitoring of children's behavior: Variation across stepmother, stepfather, and two-parent biological families. Family Relations, 52(1), 45-22.

Fuller-Thomson, E. (2000). Loss of the kin-keeper? Sibling conflict following parental death. Omega, 56(2), $547-559$.

Ganong, L. H., \& Coleman, M. (1993). An exploratory study of stepsibling relationships. Journal of Divorce and Remarriage, 19(3-4), 125-141.

Ganong, L. H., \& Coleman, M. (2004). Stepfamilies relationships: Development, Dynamics, and Interventions. Springer Science+Business Media.

Ganong, L. H., Coleman, M., Fine, M., \& Martin, P. (1999). Stepparents' affinity-seeking and affinity maintaining strategies with stepchildren. Journal of Family Issues, 20(3), 299-327.

Ganong, L. H., Coleman, M., \& Jamison, T. (2011). Patterns of stepchild - stepparent relationship development. Journal of Marriage and Family, 73(2), 396-413.

Ganong, L. H., Jensen, T., Sanner, C., Russell, L., \& Coleman, M. (2019). Stepfathers' affinity-seeking with stepchildren, stepfather-stepchild relationship quality, marital quality, and stepfamily cohesion among stepfathers and mothers. Journal of Family Psychology, 33(5), 521-531.

Gold, J. M., \& Adeyemi, O. (2013). Stepfathers and noncustodial fathers: Two men, one role. The Family Journal: Counselling and Therapy for Couples and Families 21(1), 99-103.

Greenwood, J. L. (2014). Adult sibling relationships in the context of a mid - to late-life parental divorce. Journal of Divorce \& Remarriage, 55(5), 391-407.

Gunnoe, M. L., \& Hetherington, E. M. (2004). Stepchildren's perceptions of noncustodial mothers and noncustodial fathers: Differences in socioemotional involvement and associations with adolescent adjustment problems. Journal of Family Psychology, 18(4), 555-563.

Harcourt, K. T., Adler-Baeder, F., Erath, S., \& Pettit, G. S. (2015). Examining family structure and half-sibling influence on adolescent well-being. Journal of Family Issues, 36(2), 250-272.

Henderson, S. H., \& Taylor, L. C. (1999). Parent-adolescent relationships in nonstep-, simple step-, and complex stepfamilies. In E. M. Hetherington, S. H. Henderson, \& D. Reiss (Eds.), Adolescent siblings in stepfamilies: Family functioning and adolescent adjustment. Monographs of the Society for Research in Child Development, 64(4), 79-100.

Hetherington, E. M. (1989). Coping with family transitions: Winners, losers, and survivors. Child Development, $60(1), 1-14$.

Hetherington, E. M., \& Clingempeel, W. G. (1992). Coping with marital transitions: A family systems perspective. Monographs of the Society for Research in Child Development, 57(2), 12-42.

Hofferth, S. L., Cabrera, N., Carlson, M., Coley, R. L., Day, R., \& Schindler, H. (2007). Resident father involvement and social fathering. In S. L. Hofferth \& L. M. Casper (Eds.), Handbook of measurement issues in family research (335-374). Mahwah, NJ, US: Lawrence Erlbaum Associates Publishers.

Hyblerová, P. (2011). Soudržnost mezi sourozenci v doplněné rodině. Nepublikovaná diplomová práce, Univerzita Tomáše Bati ve Zlíně, Česká republika.

Jensen, T. M., (2017). Constellations of dyadic relationship quality in stepfamilies: A factor mixture model. Journal of Family Psychology, 31(8), 1051-1062.

Jensen, T. M., \& Shafer, K. (2013). Stepfamily functioning and closeness: Children's views on second marriages and stepfather relationships. Social Work, 58(2), 127-136.

Jensen, T. M., Shafer, K., \& Holmes, E. K. (2015). Transitioning to stepfamily life: the influence of closeness with biological parents and stepparents on children's stress. Child and Family Social Work, 22(1), $275-286$.

Jensen, T. M., Shafer, K., \& Larson, J. H. (2014). (Step)parenting attitudes and expectations: Implications for stepfamily functioning and clinical intervention. The Journal of Contemporary Social Services, 95(3), $213-220$.

Kellas, J. K, Baxter, L., LeClair-Underberg, C., Thatcher, M., Routsong, T., Normand, E. L., ... Braithwaite, D. O. (2014). Telling the story of stepfamily beginnings: The relationship between young-adult 
stepchildren's stepfamily origin stories and their satisfaction with the stepfamily. Journal of Family Communication, 14(2), 149-166.

Kim, J. E., Hetherington. E. M., \& Reiss, D. (1999). Associations among family relationships, antisocial peers and adolescents' externalizing behaviors: Gender and family type differences. Child Development, 70(5), $1209-1230$.

King, V. (2007). When children have two mothers: relationships with nonresident mothers, stepmothers, and fathers. Journal of Marriage and Family, 69(5), 1178-1193.

King, V. (2009). Stepfamily formation: Implications for adolescent ties to mothers, nonresident fathers, and stepfathers. Journal of Marriage and Family, 71(4), 954-968.

King, V., Amato, P. R., \& Lindstrom, R. (2015). Stepfather-adolescent relationship quality during the first year of transitioning to a stepfamily. Journal of Marriage and Family, 77(5), 1179-1189.

King, V., \& Lindstrom, R. (2016). Continuity and change in stepfather-stepchild closeness between adolescence and early adulthood. Journal of Marriage and Family, 78(3), 730-743.

King, V., Thorsen, M. L., \& Amato, P. R. (2014). Factors associated with positive relationships between stepfathers and adolescent stepchildren. Social Science Research, 47, 16-29.

Leidy, M. S., Schofield, T. J., Miller, M. A., Parke, R. D., Coltrane, S., Braver, S., ... Adams, M. (2011). Fathering and adolescent adjustment: variations by family structure and ethnic background. Fathering, 9(1), 1-22.

Leon, K., \& Angst, E. (2005). Portrayals of Stepfamilies in Film: Using Media Images in Remarriage Education. Family Relations, 54, 3-23.

Mack, K. Y. (2004). The effects of early parental death on sibling relationships in later life. Omega, 49(2), 131-148.

Marsiglio, W. (1992). Stepfathers with minor children living at home: Parenting perceptions and relationship quality. Journal of Family Issues, 13(2), 195-214.

Matějček, Z. (1992). Ditě a rodina v psychologickém poradenství. Státní pedagogické nakladatelství.

Matoušková, K. (2017). Podmínky príietí nevlastniho otce ditětem a život ve složené rodině očima dětí a nevlastních otců. Nepublikovaná rigorózní práce. Univerzita Karlova, Česká republika.

Mekos, D., Hetherington, E. M., \& Reiss, D. (1996). Sibling differences in problem behavior and parental treatment in nondivorced and remarried families. Child Development, 67(5), 2148-2165.

Němcová, M. (2018). Sourozenecké vztahy v doplněných rodinách. Nepublikovaná bakalářská práce, Univerzita Karlova v Praze, Česká republika.

Němcová, M. (2020). Vztahy mezi členy znovusložených rodin a osobní pohoda dítěte. Nepublikovaná diplomová práce, Univerzita Karlova, Česká republika.

O’Connor, T. G., Dunn, J., Jenkins, J. M., \& Rasbash, J. (2006). Predictors of between-family and within-family variation in parent-child relationships. Journal of Child Psychology and Psychiatry, 47(5), 498-510.

Pasley, K., \& Ihinger-Tallman, M. (1985). Portraits of stepfamily life in popular literature: 1940-1980. Family Relations, 34, 527-534.

Petren, R. E., Garneau-Rosner, Ch. L., \& Yildirim, E. D. (2018). Union stability among mothers and stepfathers: Contributions of stepfathers and biological fathers. Journal of Family Psychology, 32(8), 1142-1151.

Petren, R. E., Lardier, D. T., Bible, J., Bermea, A., \& van Eeden-Moorefield, B. (2019). Parental relationship stability and parent-adult child relationships in stepfamilies: A test of alternative models. Journal of Family Psychology, 33(2), 143-153.

Poortman, A. R., \& Voorpostel, M. (2009). Parental divorce and sibling relationships: A research note. Journal of Family Issues, 30(1), 74-91.

Pryor, J. (eds.) (2008). The international handbook of stepfamilies: Policy and practice in legal, research, and clinical environments. John Wiley \& Sons, Inc.

Riggio, H. R. (2001). Relations between parental divorce and the quality of adult sibling relationships. Journal of Divorce \& Remarriage, 36(1-2), 67-82.

Roth, K. E., Harkins, D. A., \& Eng, L. A. (2014). Parental conflict during divorce as an indicator of adjustment and future relationships: A retrospective sibling study. Journal of Divorce \& Remarriage, 55(2), 117-238.

Russell, L. T., Beckmeyer, J. J., Coleman, M., \& Ganong, L. (2016). Perceived barriers to postdivorce coparenting: Differences between men and women and associations with coparenting behaviors. Family Relations, 65(3), 450-461.

Schwartz, S. J., \& Finley, G. E. (2009). Mothering, fathering, and divorce: The influence of divorce on reports of and desires for maternal and paternal involvement. Family Court Review, 47(3), 506-522. 
Sheehan, G., Darlington, Y., Noller, P., \& Feeney, J. (2004). Children's perceptions of their sibling relationships during parental separation and divorce. Journal of Divorce \& Remarriage, 41(1/2), 69-94.

Sobotková, I. (2001). Psychologie rodiny. Portál.

Stewart, S. (1999). Disneyland dads, Disneyland moms: How nonresident parent spend time with absent children. Journal of Family Issues, 20(4), 539-556.

Stocker, C. M., \& Youngblade, L. (1999). Marital conflict and parental hostility: Links with children's sibling and peer relationships. Journal of Family Psychology, 13(4), 598-609.

Svare, G. M., Jay, S., \& Mason, M. A. (2004). Stepparents on stepparenting: An exploratory study of stepparenting approaches. Journal of Divorce \& Remarriage, 41(3/4), 81-97.

Tanskanen, A. O., Danielsbacka, M., Jokela, M., \& Rotkirch, A. (2016). Sibling conflict in full - and half-sibling households in the UK. Journal of Biological science, 49(1), 1-17.

Tanskanen, A. O., Danielsbacka, M., \& Rotkirch, A. (2015). More unintended injuries in half sibling than full sibling households in the UK. Journal of Individual Differences, 36(3), 177-182.

Thomson, E., Mosley, J., Hanson, T. L., \& McLanahan, S. S. (2001). Remarriage, cohabitation, and changes in mothering behavior. Journal of Marriage and Family, 63(2), 370-380.

Tifferet, S., Jorev, S., \& Nasanovitz, R. (2010). Lower parental investment in stepchildren: the case of the Israeli "Great Journey". Journal of Social, Evolutionary and Cultural Psychology, 4(2), 62-67.

Wallerstein, J. \& Lewis, J. M. (2007). Disparate parenting and stepparenting with siblings in the post-divorce family: Report from a 10year longitudinal study. Journal of Family Studies, 13(2), 224-235.

Wallerstein, J. S., \& Lewis, J. M. (2009). Divorced fathers and their adult offspring: Report from a twenty-five-year longitudinal study. Family Law Quarterly, 42(4), 695-711.

Wallerstein, J., Lewis, J., \& Rosenthal, S. P. (2013). Mothers and their children after divorce: Report from a 25 - year longitudinal study. Psychoanalytic Psychology, 30(2), 167-187. Weaver, S. E., \& Coleman, M. (2005). A mothering but not a mother role: A grounded theory study of the nonresidential stepmother role. Journal of Social and Personal Relationships, 22(4), 477-497.

Weaver, S. E., \& Coleman, M. (2010). Caught in the middle: Mothers in stepfamilies. Journal of Social Personal Relationships, 27(3), 305-326.

White, L., \& Gilbreth, J. G. (2001). When children have two fathers: Effects of relationships with stepfathers and noncustodial fathers on adolescent outcomes. Journal of Marriage and Family, 63(1), 155-167.

Mgr. Markéta Němcová, absolventka katedry psychologie FF UK; pracuje jako psycholog ve zdravotnictví s dětskou klientelou a také jako psycholog v dětském domově, e-mail: marketan.11@gmail.com 